logos_i_ethos_2018_1_(47), s. 181-197

DOI: http://dx.doi.org/10.15633/lie.2556

Tadeusz Biesaga SDB

Uniwersytet Papieski Jana Pawła II w Krakowie

\title{
Karola Wojtyły krytyka koncepcji osoby Maxa Schelera
}

\section{W kierunku integralnego ujęcia przeżycia etycznego}

Spór Karola Wojtyły z Maxem Schelerem ujawnia $\mathrm{z}$ jednej strony jego uznanie dla osiągnięć fenomenologii, z drugiej jego krytyczną ocenę zbyt ciasnego ujęcia przeżycia etycznego. Już w doktorancie o św.
Tadeusz Biesaga SDB, ks. prof. dr hab. - filozof, etyk, bioetyk, teoretyk etyki medycznej, kierownik Katedry Bioetyki na Wydziale Filozoficznym Uniwersytetu Papieskiego Jana Pawła II w Krakowie. Rozwija personalistyczną etykę, bioetykę i etykę medyczną. Z punktu widzenia personalizmu realistycznego przeprowadza krytykę utylitaryzmu i kontraktualizmu w etyce ogólnej, bioetyce i etyce medycznej.

Janie od Krzyża Wojtyła wykorzystał wewnętrzne doświadczenie Boga do odsłonięcia istotnych cech osoby ludzkiej. Cenił doświadczenie wartości, w tym wypadku przeżycie osobowej więzi z Bogiem, które służy również odsłonięciu głębi osoby ludzkiej ${ }^{1}$. Fenomenolodzy, opisując przeżycia aksjologiczne, odsłaniali świat wartości, i tym samym ujawniali bogactwo życia osobowego. Obok jednak filozofii świadomości fenomenologów, Wojtyła zetknął się również z metafizyką św. Tomasza, która inspirowała go, aby sięgnąć szerzej i głębiej do tego, co się kryje u podstaw naszych przeżyć moralnych, estetycznych czy religijnych. Pod wpływem tych dwóch perspektyw: fenomenologicznej i metafizycznej, Wojtyła rozwijał swoją filozofię, przechodząc od fenomenu do jego bytowego fundamentu. Wybór tej drogi pozwalał mu odkryć to, co zostało słabo uwyraźnione, czy też całkowicie pominięte, albo nie zostało

1 K. Wojtyła, O humanizmie św. Jana od Krzyża, w: K. Wojtyła, Aby się Chrystus nami posługiwat, Kraków 1979, s. 387-401. 
w pełni wyjaśnione w fenomenologii wartości Maxa Schelera. Na tej drodze poszukiwał on integralnie ujętego przeżycia etycznego oraz integralnie ujętej osoby ludzkiej, sprawcy dobra moralnego.

Wydawałoby się, że kto jak kto, ale to fenomenolodzy, jako mistrzowie opisu przeżyć aksjologicznych, przedstawią adekwatny opis i analizę przeżycia etycznego. Trzeba przyznać, że znajdujemy u nich niezwykle wnikliwe opisy przeżyć wartości oraz przeżyć odpowiedzi intelektualnych, emocjonalnych i wolitywnych na wartość, wraz z opisem istotowych właściwości poszczególnych wartości w ich hierarchicznym uporządkowaniu, czyli wraz z opisem pozytywności czy negatywności wartości, ich natury, stopnia hierarchicznego i tego, co specyficzne dla wartości, szczególnie dla wartości moralnych, intelektualnych czy estetycznych ${ }^{2}$. Opisy te, ukazując wartości, odsłaniały przy okazji współprzeżywany z nimi ich osobowy podmiot, czyli życie wewnętrzne osoby.

Karol Wojtyła wyraża uznanie dla przeprowadzonych przez Maxa Schelera wnikliwych opisów zarówno emocjonalnego aktów czucia, jak i poszczególnych typów wartości, danych w tych przeżyciach. Wartości te odczuwane są a priori jako wyższe albo jako niższe. Są one słusznie związane $\mathrm{z}$ ich podmiotem, z osobą. Związek z osobą zachodzi na zasadzie przeżywania wartości i współprzeżywania osoby wraz z jednością jej przeżyć wartości. Świadomość aktowa koncentruje się na intencjonalnie danym przedmiocie, a świadomość nieaktowa sprawia, że poszczególne przeżycia przedmiotowe łączą się w strumień świadomości i wskazują na podmiot świadomy, osobowy owego ciągu aktów świadomych. Charakterystyczne dla Schelera jest ujęcie wartości w intencjonalnych aktach emocjonalnych, „które wypływają z najgłębszych źródeł życia emocjonalnego osoby, tzn. z jej miłości lub nienawiści” ${ }^{3}$. Miłość według Schelera poprzedza poznanie. „Dopiero zaś w zależności od tego,

2 M. Scheler, Der Formalismus in der Ethik und die materiale Wertethik. Neuer Versuch der Grundlegung eines ethischen Personalismus, Halle 1916, passim; D. von Hildebrand, Christian Ethics, New York 1952, passim.

${ }^{3}$ K. Wojtyła, System etyczny Maxa Schelera jako środek do opracowania etyki chrześcijańskiej, w: K. Wojtyła, Zagadnienie podmiotu moralności, red. T. Styczeń, J. W. Gałkowski, A. Rodziński, A. Szostek, Lublin 1991, s. 133 (Człowiek i Moralność, 2). 
jaki świat wartości otwiera się przed emocjonalną głębią osoby, również emocjonalne akty poznawcze ujawniają te wartości. Zarówno ich zakres, jak i hierarchia jest zawsze dana a priori w emocjonalnym przeżyciu"4. Dobro i zło etyczne jawi się przy przedkładaniu wartości przedmiotowej wyższej nad niższą. Pojawia się ono przy okazji chęci urzeczywistnienia różnorodnych wartości przedmiotowych, czyli niejako „na barkach” (auf dem Rücken) tychże wartości (przyjemnościowych, witalnych, utylitarnych i duchowych: estetycznych, intelektualnych, religijnych). Osoba przeżywa siebie samą - zdaniem Schelera - nie tylko jako podmiot wartości etycznych, lecz także jako źródło owych wartości ${ }^{5}$.

Wojtyła pochwala podjęty przez Schelera wysiłek związania wartości z osobowym centrum człowieka, dostrzega jednak słabość tego związku oraz wadliwość ujęcia osoby, która ma być źródłem wartości etycznej. Nie zgadza się zarówno z Schelerowską emotywistyczną koncepcją przeżycia etycznego, z tym, że dotyczy ono tylko treści przeżywanych wartości, a nie wprost dobra moralnego, że postępowanie etyczne to tylko przeżywanie czy też przeżywaniowe przedkładanie jednych wartości nad drugie, jak i z tym, że osoba jest wyłącznie jednością świadomych przeżyć. Nie podziela opinii, że wartość etyczna konstytuuje się niejako przy biernej postawie osoby, na płaszczyźnie jej przeżyć emocjonalnych innych wartości oraz że wartość etyczna jest wartością „dodatkową", a nie pierwszorzędną, rozpoznaną, zamierzoną i doskonalącą osobę. Jego zdaniem Scheler w analizie sfery etycznej pominął rolę woli osoby, autodeterminacji i sprawczości osoby w konstytuowaniu się wartości etycznej. Samo emocjonalne przeżywanie wartości i esencjalne ich ujęcie nie tworzy wartości etycznej. Namysł teoretyczny nad wartościami przedmiotowymi nie tworzy norm postępowania praktycznego. Mimo przedstawienia opisu przeżycia wartości, filozof pominął przeżycie powinności moralnej, które wyznacza wartość etyczną udoskonalającą osobę. Dla powstania wartości etycznej konieczny jest apel powinności

${ }^{4}$ K. Wojtyła, System etyczny Maxa Schelera jako środek do opracowania..., dz. cyt., s. 133.

5 K. Wojtyła, Zagadnienie woli w analizie aktu etycznego, w: K. Wojtyła, Zagadnienie podmiotu moralności, dz. cyt., s. 181-200, s. 196. 
skierowany do naszej woli, potrzebne jest praktyczne działanie, realizujące to, co osobę udoskonala. Przez przeakcentowanie sfery emocjonalnej i zignorowanie sfery sprawczej osoby Scheler nie potrafił ująć całej rzeczywistości etycznej, czyli przywołać i zharmonizować wszystkich elementów przeżycia etycznego, tego, czym ono jest, jak się realizuje wartość etyczna, oraz tego, że osoba jest sprawcą, realnym źródłem wartości etycznej. „Osoba przeżywa siebie jako przyczynę sprawczą swych czynów - stwierdza Wojtyła - i z tym przeżyciem wiąże się wartość etyczna. Scheler tej sprawczości nie dostrzegał, był on w założeniach swoich nie tylko emocjonalistą, ale przede wszystkim fenomenologiem-esencjalistą. $\mathrm{Z}$ tego powodu brakowało mu narzędzia do tego, aby ujawnić i zobiektywizować taki czynnik dynamiczny, jakim jest wola"6.

Wojtyła rozumie przeżycie etyczne inaczej i szerzej niż Scheler. Przeżycie to związane jest według niego $\mathrm{z}$ normatywnym skierowaniem naszych czynów do dobra moralnego. Doświadczamy, że nasze „ja” osobowe jest sprawcą czynu, oraz doświadczamy zasady, która kieruje nas do dobra moralnego i w następstwie pozwala nam ocenić nasz czyn jako dobry lub zły. Zasada ta ujawnia się w naszym przeżyciu przez sumienie, które bezpośrednio stawia nas wobec dobra i zła moralnego. „Dobro i zło moralne samo w sobie - napisze Wojtyła - jest rzeczywistością bogatszą i bardziej złożoną, aniżeli zdolny jest wskazać termin «wartość moralna»" "Zasada dobra i zła jest czymś pierwotniejszym, niezbędnym i konstytutywnym dla naszego przeżycia etycznego. Normatywny aspekt moralności włącza w moralność aspekt aksjologiczny. To ten pierwszy kształtuje i nadaje wartościom charakter zobowiązania moralnego. W związku z tym kategorie aksjologiczne, w których Scheler chce ująć całą moralność, są wtórne i zależne od normy moralności. „Jest rzeczą niemożliwą - stwierdza za Wojtyłą Andrzej Półtawski - wyrażenie złożonej rzeczywistości dobra i zła moralnego w kategoriach czysto aksjologicznych, jako wartości pozytywnej czy negatywnej; właściwy sens

${ }^{6}$ K. Wojtyła, Zagadnienie woli w analizie aktu etycznego, dz. cyt., s. 197.

7 K. Wojtyła, Problem teorii moralności, w: W nurcie zagadnień posoborowych, red. B. Bejze, t. 3, Warszawa 1969, s. 230. 
terminu «wartość» implikuje bowiem coś pozytywnego, zaś mówienie o «wartości negatywnej» czy «przeciw-wartości» nie odpowiada treści naszego doświadczenia moralnego" 8

Postępowanie etyczne to nie tyle intencjonalne przeżywanie różnorodnych treści wartości, ile realizacja w czynie wartości osobowych, wartości etycznych. Osoba jest świadoma, że to ona dokonuje danego czynu, że ona jest sprawcą danej wartości etycznej. Jest świadoma swej odpowiedzialności za swój czyn. Tak więc „rdzeniem przeżycia etycznego jest sprawczość osoby wraz z motywacją. Jednakże istotowym rdzeniem przeżycia etycznego jest sama wartość etyczna"'. Nie jest ona czymś drugorzędnym, niezamierzonym, czymś niejako ubocznym, jak twierdził Scheler, lecz czymś pierwszorzędnym, poruszającym wolę do działania.

W interpretacji wartości etycznej Wojtyła przekracza poziom fenomenu i fenomenologii i zauważa, że „wartość etyczna istotą swoją tkwi w porządku pozafenomenologicznym. [...] Wartością etyczną bowiem nazywamy to, przez co człowiek jako człowiek, jako konkretna osoba, jest po prostu dobry lub zły"10. Pełne wyjaśnienie wartości etycznej wymaga przywołania nie tylko tego, co dzieje się w przeżyciach osoby, ale sięgnięcia po to, co dzieje się z osobą przez jej czyn, który spełnia, co dzieje się z nią jako bytem osobowym. Wyjaśnienie tej głębszej sfery musi sięgnąć poza „ja” fenomenologiczne, do „ja” metafizycznego, do metafizyki osoby.

Tak więc propozycji etyki Schelera nie da się uzupełnić poprzez dodanie do niej brakujących elementów, powinności, sumienia, wartości etycznej, sprawczości osoby. Wymaga ona całkowitej przebudowy, albowiem nie ujmuje tego, czym jest rzeczywistość etyczna. Nie tylko pomija takie fakty, jak sprawczość osoby, powinność, norma, sumienie, ale zniekształca interpretację postępowania moralnego. Taka sytuacja wymaga nie tyle uzupełnienia danych etycznych o brakujące fakty, ile

8 A. Półtawski, Fenomenologiczne podstawy etyki według Karola Wojtyły, w: Jan Paweł II. Posługa myślenia, red. J. Kupczak OP, D. Radziechowski, Kraków 2011, s. 35 (Studia nad Myślą Jana Pawła II, 9).

9 K. Wojtyła, Zagadnienie woli w analizie aktu etycznego, dz. cyt., s. 198.

10 K. Wojtyła, Zagadnienie woli w analizie aktu etycznego, dz. cyt., s. 198. 
przekroczenia ograniczeń zastosowanej przez Schelera metody filozoficznej, czyli przekroczenia jej esencjalizmu na rzecz otwarcia się na interpretacje realistyczne, na wyjaśnienia metafizyczne.

Tak więc Wojtyła w krytyce etyki Schelera ujawnia zarówno pominięcie ważnych faktów rzeczywistości etycznej, jak też bezsilność tej etyki w przyznaniu właściwego miejsca sumieniu, powinności moralnej, normie moralności, sprawczości, celowemu działaniu człowieka, realizacji tego, co doskonali osobę.

\section{Sumienie i powinność w przeżyciu etycznym}

Pominięcie lub zbyt ciasne ujęcie faktów etycznych przez Schelera ujawnia się m.in. przy jego trudnościach $\mathrm{z}$ włączeniem powinności moralnej oraz sumienia w swój system etyczny. W przesadnej reakcji na etykę imperatywów kategorycznych Immanuela Kanta Max Scheler wyrugował ze swej propozycji etycznej moment powinności. Formalne a priori Kanta, stojące u podstaw kategorycznych nakazów, zastąpił a priori materialnym, stojących u podstaw struktury przeżyć wartości. Moralność została zredukowana do emocjonalnego przeżywania wartości. Nakaz został usunięty z etyki, jako element opresyjny, niszczący miłość i emocjonalne przeżycia wartości. Takie postawienie sprawy szło w parze z pominięciem roli woli osoby i sprawczości osoby w czynie.

Zdaniem Wojtyły Scheler pojął powinność zasadniczo jako źródło negatywizmu w etyce, źródło zakazów w stosunku do tego, co złe. W przekonaniu Schelera „nawet wówczas, gdy [powinność] nakłada obowiązek czynienia dobrze, zmierza właściwie ze swej natury do tego tylko, ażeby wykluczyć zło temu dobru przeciwne. Samego dobra nie ma za przedmiot" ${ }^{11}$. Wojtyła odrzuca powyższą, błędną interpretację powinności moralnej. Twierdzi wprost przeciwnie, że przedmiotem powinności jest dobro. Powodem wyrugowania powinności przez Schelera jest zacieśnienie rzeczywistości etycznej jedynie do płaszczyzny emocjonalnych, intencjonalnych odczuć wartości. W tej perspektywie „odczucie

11 K. Wojtyła, System etyczny Maxa Schelera jako środek do opracowania..., dz. cyt., s. 136. 
powinności wiąże się zawsze $\mathrm{z}$ aktualną nieobecnością wartości pozytywnej, która dopiero ma zaistnieć, albo też z aktualną obecnością wartości negatywnej, której powinno nie być. I w jednym, i w drugim wypadku zachodzi wystarczająca podstawa do tego, ażeby odczucie intencjonalne przybrało negatywny charakter. Tylko w odczuciu aktualnej wartości pozytywnej przybiera ono charakter pozytywny"12. Jeśli jednak wartość już jest, to znika powinność jej realizacji. Wartość jako taka w systemie Schelera jest obojętna na realizację, a więc tym bardziej znika powinność. Przez takie postawienie sprawy wartość etyczna skazana jest na nieurzeczywistnienie.

Jeśli jednak przywołamy pominiętą przez Schelera funkcję woli osoby ludzkiej, sprawczości osoby w czynie, to powinność moralna okazuje się pozytywnym wezwaniem woli do realizacji dobrego czynu. Zgodnie z tym, co twierdzi Scheler, wartość jest obojętna na istnienie i sama w sobie nie wywołuje powinności, nie porusza woli do działania. Obok wartości potrzebny jest w działaniu etycznym inny element, czyli poruszająca naszą wolę powinność moralna. „Wypływa [ona] - pisze Wojtyła - z rozkazu bądź to zewnętrznego, bądź to wewnętrznego. Ów rozkaz zawiera żądanie pod adresem chcenia. Następstwem takiego rozkazu jest, że wartość przedmiotowa staje się przedmiotem chcenia"13. Tak więc urzeczywistnienie wartości zależy od powinności. Jeśli życie etyczne ma być realne, to nie wystarczy emocjonalnie przeżycie wartości, ale przeżycie powinności musi poruszyć wolę do czynu. Porusza ją w wyniku poznania wartości etycznej, która ujawnia swoją kategoryczność i przynagla osobę do jej spełnienia. Zarówno poznawcze, jak i emocjonalne przeżycie wartości, zdaniem Schelera, ma znaczenie właśnie ze względu na urzeczywistnienie wartości. Niestety, w zaproponowanej etyce pominięto sprawczy „mechanizm” owego urzeczywistnienia. Emocjonalne przeżywanie wartości dla samego przeżywania jest czymś pasywnym, nie jest spełnieniem czynu realizującego wartości etyczne. Etyka emocjonalnych odczuć wartości nie ma możliwości ująć pełnego

12 K. Wojtyła, System etyczny Maxa Schelera jako środek do opracowania..., dz. cyt., s. 136.

13 K. Wojtyła, System etyczny Maxa Schelera jako środek do opracowania..., dz. cyt., s. 139. 
dynamizmu osoby, opisuje go raczej od strony pasywnej, a nie od strony dynamicznej, od strony sprawczej realizacji dobrych czynów.

Wojtyła jest zaskoczony tym, że Scheler nie skorygował swego systemu etycznego ze względu na nieodzowną rolę sumienia. Fakt sumienia jest nam przecież bezpośrednio dostępny w przeżyciu etycznym. Można rozwinąć opis tego przeżycia, podobnie jak relacjonowane są opisy przeżycia wartości. Fenomen sumienia nie tylko wprost ujawnia się w naszej świadomości, ale można powiedzieć, że przez swoje nakazy, poczucie winy, wprost się nam narzuca, i stąd trudno go pominąć. Fenomenologiczne opisy poczucia winy z łatwością przedstawiają specyfikę sumienia i jego normatywny wymiar. Tymczasem Scheler pomija taki opis i „wyłącza właściwie sumienie z moralnego życia osoby”"14.

Porusza on kwestię sumienia przy okazji omawiania wolności sumienia. Nie analizuje, czym jest sumienie jako takie: czy jest sądem rozumu, czy aktem przeżyć emocjonalnych, czy też aktem decyzji woli ${ }^{15}$. Dla niego sfera emocjonalnych przeżyć i sfera wolności jako niezależności stają się zasadnicze. Sumienie miało jego zdaniem swoje oparcie w religijno-metafizycznych ujęciach, w których przedstawiano je jako głos Boga, głos natury osoby ludzkiej czy głos rozumu. Kiedy się jednak owe założenia zawiesi, traci ono swe podstawy i jako emocjonalne przeżycie, staje się, zdaniem Schelera, „zasadą anarchii” ${ }^{16}$. Bez powyższych uzasadnień sumienie staje się nieprzydatne dla moralności, a do tego, tak jak wszelka powinność, obciążone jest jeszcze negatywnością. Negatywność ta płynie stąd, że sumienie zakazuje czy nakazuje, czyli zmusza nas do czegoś, a przymus nie jest miłością, niweczy emocjonalną akceptację wartości czy też akceptację siebie.

Tymczasem sumienie stawia nas bezpośrednio w kontekście dobra i zła moralnego. Sądy sumienia wydawane są w kontekście zasady

14 K. Wojtyła, Ocena możliwości zbudowania etyki chrześcijańskiej przy założeniach systemu Maxa Schelera, w: K. Wojtyła, Zagadnienie podmiotu moralności, dz. cyt., s. 80.

15 Zob. T. Biesaga, Sumienie, w: Powszechna encyklopedia filozofii, red. A. Maryniarczyk i in., t. 9, Lublin 2008, s. 267-270.

16 K. Wojtyła, Ocena możliwości zbudowania etyki chrześcijańskiej przy założeniach systemu Maxa Schelera, dz. cyt., s. 78. 
„dobro należy czynić, zła unikać". To ono nadaje normatywny charakter przeżywanym wartościom. Rozpoznanie dobra moralnego jest wcześniejsze od preferowania wartości. Dobro moralne nie pojawia się w wyniku preferowania, jak chciał Scheler, lecz odwrotnie, preferowanie dokonywane jest w kontekście dobra moralnego. Sumienie kieruje nas bezpośrednio ku temu dobru, a nie ku emocjonalnej przyjemności pochodzącej z realizacji tego dobra. Radość czy satysfakcja z dobrego czynu przychodzi wraz ze zrealizowanym dobrem, a nie odwrotnie. Podejmujemy czyn ze względu na to dobro, a nie ze względu na satysfakcję z niego. Świadomość refleksyjna jest czymś wtórnym - według Wojtyły - do świadomości recepcyjnej, odzwierciedlającej zastane fakty i związanej prawdą o dobru.

W wyniku wyrugowania przez Schelera sumienia ze swej etyki trudno w niej znaleźć normę czy miarę, którą odmierzamy siebie, i która pozwala nam ocenić, czy spełniliśmy dobry czy zły czyn. Trudno stwierdzić czy przez dany czyn stajemy się dobrym czy złym człowiekiem. Samo przeżywanie miłości do siebie czy do innych, jak też samo przeżywanie emocjonalne różnorodnych wartości, nie daje nam takiej miary. Przeżywamy to, co przeżywamy, np. wartości utylitarne, witalne, estetyczne i inne, i trudno na tej podstawie powiedzieć, czy uczyniliśmy coś dobrego czy coś złego. Samo przeżywanie emocjonalne nie ujawnia w pełni dynamizmu rozumu ludzkiego szukającego prawdy ani dynamizmu woli zmierzającej do realizacji dobra, do którego w sumieniu została zobowiązana. To właśnie sumienie - norma normans - jest tą miarą, według której człowiek wewnętrznie odmierza swój czyn i siebie samego. Sumienie: czy to jako przekonanie, czy jako ocena, jako zobowiązanie, jako nakaz lub zakaz dotyczy naszego sprawstwa, czyli tego, co mamy uczynić, a więc dotyczy naszego czynu. Wyraźnie odnosi nas ono do dobra moralnego, które winniśmy czynić, i do zła, którego winniśmy unikać. Nie chodzi w nim o emocjonalne przeżywanie przyjemności z dokonanego dobra, ale o przedmiotowe dobro, bezpośrednio poznane i zrealizowane. 


\section{Sprawczość osoby w czynie}

Można powiedzieć, że odkrycie przez Wojtyłę braków etyki Schelera nie pozostało bez echa dla jego dalszej twórczości filozoficznej, lecz wyznaczyło nowy obszar badań, czyli poszukiwań takich uzupełnień, w których adekwatnie udałoby się opisać rzeczywistość etyczną, dobro, wartość, powinność, sprawczość i spełnienie się osoby w czynie. Świadczą o tym zarówno dalsze jego publikacje, jak i zasadnicze jego studium i osiągnięcie filozoficzne w postaci dzieła Osoba i czyn ${ }^{17}$. Analizy i wnioski z pracy habilitacyjnej, w których Wojtyła wykazał, że system etyczny Schelera nie nadaje się do wykorzystania w etyce chrześcijańskiej, kierowały go do poszukiwania takiego ujęcia antropologicznego, które umożliwiałoby interpretację bogactwa chrześcijańskiej etyki.

Dostrzeżenie owych braków etyki fenomenologicznej nie wynikało jednak ze zwykłego porównania etyki Schelera $\mathrm{z}$ etyką św. Tomasza z Akwinu, ale z czegoś więcej, z wykazania istotnych braków na terenie samej etyki zaproponowanej przez fenomenologię i kryjących się za tym założeń filozoficznych. Były to zarzuty istotne. Okazało się bowiem, że w zaproponowanej etyce aksjologicznej wyrugowano osobowe sprawstwo czynu, normatywne funkcjonowanie sumienia, powinność moralną, wartości etyczne, czyli właściwe rozumienie dobra moralnego i praktyczną jego realizację. Stało się to w wyniku zacieśnienia rzeczywistości etycznej do emocjonalnego a priori, co zamykało etykę w sferze fenomenów i apriorycznych struktur, bez możliwości poszukiwania głębszych, antropologicznych i metafizycznych podstaw faktów etycznych. Podjęcie wysiłku poszerzenia filozofii świadomości o filozofię bytu było poważnym przedsięwzięciem. Można powiedzieć, że przedsięwzięcie to, niezależnie od jego oceny, wyznaczało drogę dla filozofii, która chce rzeczywistego powrotu do rzeczy, chce mówić nie tylko o tym, co pomyślane, ale o tym, co realnie istniejące, co jest realną kondycją człowieka.

17 K. Wojtyła, „Osoba i czyn” oraz inne studia antropologiczne, red. T. Styczeń, W. Chudy, J. W. Gałkowski, A. Rodziński, A. Szostek, Lublin 1994 (Człowiek i Moralność, 4). 
Ów powrót do realnej rzeczywistości etycznej prowadzi Wojtyła, analizując pominięte przez Schelera sprawstwo osobowe czynu. „Przy fenomenologicznych założeniach jego systemu - pisze on - akty dane li tylko w spełnieniu, w przeżyciu, stanowią współprzeżywaną jedność osoby. Natomiast samo wypływanie tychże aktów z osoby, ich rodzenie się w niej, nie pozwala się według Schelera fenomenologicznie ująć i uprzedmiotowić. Osoba nie jest przyczyną sprawczą swoich aktów, one tylko "pojawiają się» w niej. Tym bardziej więc nie może występować jako przyczyna sprawcza dobra lub zła moralnego tychże aktów"18.

Tymczasem w etyce jako nauce praktycznej nie chodzi tylko o emocjonalne przeżywanie wartości, ale o zaangażowanie wolności, o decyzję woli, o podjęcie działania skierowanego i realizującego konkretne dobro osoby. W czynie nie chodzi o wartości będące jedynie treścią emocjonalnego, intencjonalnego odczucia, ale o wartość etyczną, która jako wartość osobowa realnie doskonali osobę.

Wojtyła zarzuca Schelerowi, że w wyniku swoich emocjonalistycznych założeń utożsamił „chcenie dobra” $\mathrm{z}$ „chceniem odczuwania, że jest się dobrym". Nic dziwnego, że takie dążenie do przeżywania swej dobroci nazwał faryzeizmem. Tymczasem według Wojtyły, „«chcieć być dobrym» to oznacza dążenie woli w stronę samej przedmiotowej wartości, a nie oznacza bynajmniej "chcieć dobra» jako przedmiotowej treści podmiotowego odczucia"19. W dążeniu do realizacji ideału własnej doskonałości nie chodzi o własne intencjonalne odczucie przyjemności z tej doskonałości, ale o realizację samego ideału jako takiego. Dla Schelera wartości jawią się najpierw w przeżyciu emocjonalnym (miłość - nienawiść) i następnie w emocjonalno-poznawczym odczuciu intencjonalnym, przez co zamknięta jest droga do uchwycenia poznawczo-wolitywnej sprawczości osoby. W powyższej opcji dobrze odkryte i uporządkowane jest emocjonalno-poznawcze przeżywanie

${ }_{18} \mathrm{~K}$. Wojtyła, Ocena możliwości zbudowania etyki chrześcijańskiej przy założeniach systemu Maxa Schelera, dz. cyt., s. 67.

19 K. Wojtyła, Ocena możliwości zbudowania etyki chrześcijańskiej przy założeniach systemu Maxa Schelera, dz. cyt., s. 69. 
wartości, ale wykluczona jest poznawczo-wolitywna realizacja dobra moralnego. „Scheler nie dotarł - stwierdza Wojtyła - do samej istoty praktycznego porządku, nie uchwycił bowiem momentu sprawczości

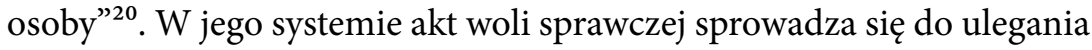
pewnemu oddziaływaniu emocjonalnemu. „Wola tylko ulega pociągowi emocjonalnemu zrodzonemu $\mathrm{z}$ emocji" ${ }^{21}$. Brakuje w tym ujęciu niejako własnej dynamiki chcenia, w którym wola skupia się na celu działania i podejmuje to działanie. „Skoro osoba w chceniu stawia sobie wartości jako cele - stwierdza Wojtyła - to znaczy, że pozostaje do nich w sprawczym stosunku"22.

W ten sposób przywraca on etyce jej praktyczny charakter, przezwycięża emocjonalistyczne ujęcie przeżycia etycznego, ujawnia właściwą funkcję poznania receptywnego, funkcję sumienia i woli w jej skierowaniu i realizacji dobra-celu działania. Takie ujęcie zasadniczo modyfikuje etykę Schelera, a właściwie reinterpretuje ją w duchu klasycznej, realistycznej etyki oraz związanej z nią personalistycznej antropologii, a nawet realistycznej metafizyki bytu ludzkiego. Propozycję takiej antropologii spotykamy w szczytowym dziele Wojtyły Osoba $i$ czyn. Została w nim wyraźne odróżniona świadomość receptywna, odzwierciedlająca od świadomości refleksyjnej. Dzieło stanowi obszerne studium sprawczości osoby jako samoopanowania, samoposiadania, samostanowienia wraz ze spełnieniem oraz studium wolności, autodeterminacji, transcendencji osoby w czynie, poprzez przyporządkowanie wolności prawdzie o dobru ${ }^{23}$.

${ }^{20}$ K. Wojtyła, Ocena możliwości zbudowania etyki chrześcijańskiej przy założeniach systemu Maxa Schelera, dz. cyt., s. 74.

${ }^{21}$ K. Wojtyła, Ocena możliwości zbudowania etyki chrześcijańskiej przy założeniach systemu Maxa Schelera, dz. cyt., s. 75.

${ }^{22}$ K. Wojtyła, Ocena możliwości zbudowania etyki chrześcijańskiej przy założeniach systemu Maxa Schelera, dz. cyt., s. 74 .

${ }^{23}$ K. Wojtyła, „Osoba i czyn” oraz inne studia..., dz. cyt., s. 73-228. 


\section{Fenomenologiczne a metafizyczne ujęcie osoby}

Mimo wysuwania postulatu „powrotu do rzeczy” fenomenologom nie udało się go zrealizować, gdyż uniemożliwiały to przyjęte założenia epistemologiczne. Być może najdalej w ontologii osobowego „ja” posunął się Roman Ingarden, dochodząc do wniosku, że bez stabilnego „ja” osobowego nie jest możliwa odpowiedzialność moralna ${ }^{24}$. Scheler nie posunął swych badań tak daleko w kierunku ontologii osoby, a tym bardziej nie rozwinął metafizyki bytu ludzkiego. Osoba w jego fenomenologii, która ujawnia się w współprzeżywaniu przeżyć wartości, jest czymś tylko zjawiskowym, kruchym. Zarówno wartości, jak i osoba są jedynie treścią odczuć, treścią świadomości. „Ponieważ treści te są obojętne na istnienie - stwierdza Wojtyła - zatem można mówić o sui generis esencjalizmie w jego koncepcji wartości. Esencjalizm ten idzie $\mathrm{w}$ parze $\mathrm{z}$ niedostrzeganiem sprawczego stosunku osoby względem wartości etycznych. Tak więc od strony podmiotu wartości, czyli osoby, esencjalizm przechodzi w aktualizm. Scheler bowiem przeczy istnieniu osoby jako substancjalnego bytu, który działa, zastępując byt przez sumę aktów, czyli przeżyć współprzeżywanych w przeżyciu osobowej jedności"25.

Na terenie owego fenomenalizmu, esencjalizmu i aktualizmu Scheler nie potrafił dostrzec sprawczości osoby, która przez czyn dobry aktualizuje potencjalność swej natury osobowej, spełnia siebie, stając się dobrym człowiekiem. „Osoba w koncepcji Schelera - pisze Wojtyła - nie jest bytem, ale jest tylko jednością przeżyć. W każdym przeżyciu, np. w odczuciu wartości lub w chceniu, współprzeżywamy również tę jedność, jaką tworzą wszystkie przeżycia. I tylko ta uświadamiana jedność przeżyć, jedność aktów, jest osobą. Osoba zatem w ujęciu Schelera nie

${ }^{24}$ R. Ingarden, O odpowiedzialności i jej podstawach ontycznych, w: R. Ingarden, Książeczka o człowieku, Kraków 1987, s. 71-170.

${ }^{25} \mathrm{~K}$. Wojtyła, Ocena możliwości zbudowania etyki chrześcijańskiej przy założeniach systemu Maxa Schelera, dz. cyt., s. 120 
jest bytem, ale tylko i wyłącznie świadomością. Jest to świadomość bycia osobą, ale nie jest to obiektywny byt osobowy" ${ }^{26}$.

Wojtyła odrzuca oderwanie świadomości osoby od realnego istnienia osoby. Takie redukcjonistyczne, idealistyczne ujęcie człowieka nie nadaje się do adekwatnego wyjaśnienia postępowania moralnego, do ukazania realnej sprawczości osoby, celowościowego działania, wyodrębniania się i zasadniczej roli dobra, funkcjonowania sumienia, powinności czy nakazów moralnych, doskonalenia się osoby poprzez czyn. To jest możliwe tylko przy realistycznym ujęciu osobowego „ja”, jako „ja” antropologicznego, ,ja" metafizycznego, które wyposażone w potencjalności bytowe, aktualizuje je, aktualizując tym samym naturę osoby. „Świadomość jest ujęta realistycznie wówczas - napisze Wojtyła - gdy wiąże się z bytem ludzkim jako ze swym podmiotem, gdy stanowi jego akt" ${ }^{27}$. Świadomość jako podmiot intencjonalnych treści wartości, „nie może być podmiotem wartości jako tego, co realnie doskonali byt" ${ }^{28}$. W ujęciu realistycznym „dobro moralne nie jest tylko treścią świadomości, ale jest równocześnie doskonałością bytu świadomego - i owszem, tym ostatnim jest przede wszystkim. Doskonałość bytu można ująć tylko w drodze analizy bytu" 29 .

Tak więc realistycznie rozwijana etyka domaga się realistycznej metafizyki człowieka. Nie chodzi w niej bowiem tylko o świadomościowe przeżywanie treści wartości, ale chodzi o stawanie się przez czyn dobrym człowiekiem. Takie stawanie się można określić tylko dzięki integralnemu ujęciu człowieka. W związku z powyższym sama fenomenologia świadomości jest niewystarczająca do zbudowania etyki i oparcia jej na realistycznej koncepcji człowieka. Filozofia świadomości, bez ugruntowania jej w filozofii bytu, zniekształca bowiem właściwe rozpoznanie dobra moralnego, sumienia, powinności moralnych, wartości etycznych, sprawczego działania osoby, tego wszystkiego, co doskonali osobę.

26 K. Wojtyła, W poszukiwaniu podstaw perfekcjoryzmu w etyce, w: K. Wojtyła, Zagadnienie podmiotu moralności, dz. cyt., s. 211.

${ }^{27}$ K. Wojtyła, W poszukiwaniu podstaw perfekcjoryzmu w etyce, dz. cyt., s. 211.

${ }^{28}$ K. Wojtyła, W poszukiwaniu podstaw perfekcjoryzmu w etyce, dz. cyt., s. 211.

${ }^{29} \mathrm{~K}$. Wojtyła, W poszukiwaniu podstaw perfekcjoryzmu w etyce, dz. cyt., s. 211. 
Podobną krytykę ciasnych koncepcji osoby, wykluczających z grona osób tych ludzi, którzy aktualnie nie są świadomi czy samoświadomi siebie, można spotkać m.in. w pracach Josefa Seiferta ${ }^{30}$, Roberta Spaemanna ${ }^{31}$, Tadeusza Biesagi $^{32}$ i Grzegorza Hołuba ${ }^{33}$.

\section{Bibliografia}

Biesaga T., Pojęcie osoby a zasada jakości życia we współczesnej bioetyce, w: Ocalić cywilizację - ocalić ludzkie życie, red. Z. Morawiec, Kraków 2002, s. 53-64.

Biesaga T., Sumienie, w: Powszechna encyklopedia filozoficzna, red. A. Maryniarczyk i in., t. 9, Lublin 2008, s. 267-270.

Hildebrand D. von, Christian Ethics, New York 1952.

Hołub G., Problem osoby we wspótczesnych debatach bioetycznych, Kraków 2010.

Ingarden R., O odpowiedzialności i jej podstawach ontycznych, w: R. Ingarden, Książeczka o człowieku, Kraków 1987, s. 71-170.

Półtawski A., Fenomenologiczne podstawy etyki według Karola Wojtyły, w: Jan Paweł II.

Posługa myślenia, red. J. Kupczak OP, D. Radziechowski, Kraków 2011, s. 33-42 (Studia nad Myślą Jana Pawła II, 9).

Scheler M., Der Formalismus in der Ethik und die materiale Wertethik. Neuer Versuch der Grundlegung eines ethischen Personalismus, Halle 1916.

Seifert J., The Right to Life and the Fourfold Root of Human Dignity, w: The Nature and Dignity of the Human Person as the Foundation of the Right to Life, the Challenges of the Contemporary Cultural Context, Proceedings of the VIII Assembly of the Pontifical Academy For Life (Vatican City, 25-27.02. 2002), eds. J. De Dios Vial Correa, E. Sgreccia, Vatican City 2003, s. 183-215.

30 J. Seifert, The Right to Life and the Fourfold Root of Human Dignity, w: The Nature and Dignity of the Human Person as the Foundation of the Right to Life, the Challenges of the Contemporary Cultural Context, Proceedings of the VIII Assembly of the Pontifical Academy For Life (Vatican City, 25-27.02. 2002), eds. J. De Dios Vial Correa, E. Sgreccia, Vatican City 2003, s. 183-215.

31 R. Spaemann, Osoby. O różnicy między czymś a kimś, tłum. J. Merecki, Warszawa 2001.

32 T. Biesaga, Pojęcie osoby a zasada jakości życia we współczesnej bioetyce, w: Ocalić cywilizację-ocalić ludzkie życie, red. Z. Morawiec, Kraków 2002, s. 53-64.

${ }^{33}$ G. Hołub, Problem osoby we współczesnych debatach bioetycznych, Kraków 2010. 
Spaemann R., Osoby. O różnicy między czymś a kimś, tłum. J. Merecki, Warszawa 2001. Wojtyła K., O humanizmie św. Jana od Krzyża, w: K. Wojtyła, Aby się Chrystus nami postugiwał, Kraków 1979, s. 387-401.

Wojtyła K., Ocena możliwości zbudowania etyki chrześcijańskiej przy założeniach systemu Maxa Schelera, w: K. Wojtyła, Zagadnienie podmiotu moralności, red. T. Styczeń, J. W. Gałkowski, A. Rodziński, A. Szostek, Lublin 1991, s. 7-128 (Człowiek i Moralność, 2).

Wojtyła K., „Osoba i czyn” oraz inne studia antropologiczne, red. T. Styczeń, W. Chudy, J. W. Gałkowski, A. Rodziński, A. Szostek, Lublin 1994 (Człowiek i Moralność, 4).

Wojtyła K., Problem teorii moralności, w: W nurcie zagadnień posoborowych, red. B. Bejze, t. 3, Warszawa 1969, s. 217-251.

Wojtyła K., System etyczny Maxa Schelera jako środek do opracowania etyki chrześcijańskiej, w: K. Wojtyła, Zagadnienie podmiotu moralności, red. T. Styczeń, J. W. Gałkowski, A. Rodziński, A. Szostek, Lublin 1991, s. 129-158 (Człowiek i Moralność, 2).

Wojtyła K., W poszukiwaniu podstaw perfekcjoryzmu w etyce, w: K. Wojtyła, Zagadnienie podmiotu moralności, red. T. Styczeń, J. W. Gałkowski, A. Rodziński, A. Szostek, Lublin 1991, s. 201-212 (Człowiek i Moralność, 2).

Wojtyła K., Zagadnienie woli w analizie aktu etycznego, w: K. Wojtyła, Zagadnienie podmiotu moralności, red. T. Styczeń, J. W. Gałkowski, A. Rodziński, A. Szostek, Lublin 1991, s. 181-200 (Człowiek i Moralność, 2).

\section{Abstrakt}

\section{Karola Wojtyły krytyka koncepcji osoby Maxa Schelera}

Artykuł rekonstruuje Karola Wojtyły krytykę koncepcji osoby, świadomości, przeżycia etycznego autorstwa Maxa Schelera. Scheler, zdaniem Wojtyły, oderwał w swej etyce świadomość od istnienia osoby, zacieśnił przeżycie etyczne do emocjonalnego przeżywania wartości, wyrugował osobowe sprawstwo czynu, normatywne funkcjonowanie sumienia, powinność moralną, wartości etyczne, czyli zniekształcił właściwe rozumienie dobra moralnego i jego praktyczną realizację.

Osoba, według krakowskiego myśliciela, nie jest sumą świadomych przeżyć, ale realnie istniejącym bytem, aktualizującym się $\mathrm{w}$ aktach poznania i w aktach działania. Świadomość nie może być oderwana od realnego istnienia osoby, gdyż jest jej aktem. 
Przeżycie etyczne to nie tylko doznanie treści wartości, ale doświadczenie powinności moralnej, nakazu sumienia, doświadczenie tego, że jestem sprawcą czynu.

W sumie propozycja etyki Schelera, zdaniem jej krytyka, nie nadaje się do adekwatnego wyjaśnienia postępowania moralnego, do ukazania realnej sprawczości osoby i jej doskonalenia się poprzez czyn.

\section{Słowa kluczowe}

osoba, świadomość, sprawczość osoby, przeżycie etyczne, sumienie

\section{Abstract \\ Karol Wojtyła's Criticism of Max Scheler's Concept of a Person}

The paper reconstructs Karol Wojtyła's criticism of Max Scheler's concept of a person, consciousness, and ethical experience. As underlined by Wojtyła, in the ethics of Scheler the concepts of consciousness and existence of a person are treated separately and the ethical experience is reduced to emotional experience of values. In addition, in the proposals of Scheler the personal agency which allows one to act, the normative functioning of the conscience as well as the moral obligation and the ethical values, are all eradicated. In other words, the proper understanding of the moral good and its practical implementation are distorted.

According to the Cracovian thinker, the person is not a sum of conscious experiences, but it rather is a truly existing entity that actualises itself in the acts of cognition and in the acts of action. Consciousness cannot be detached from the real existence of a person, because it is its act. Ethical experience is not only an experience of the content of values, but it is also an experience of the moral obligation and the conscience order, as well as the experience of being an agent and have the capacity to act.

According to the Wojtyła's criticism of the proposal of ethics of Scheler, the latter is neither suitable for an adequate explanation of moral behavior, nor to picture the true agency of a person and its improvement that takes place through its actions.

\section{Keywords}

person, consciousness, human agency, ethical experience, conscience 